\title{
International Development Policies and Coastalscape Metabolism: The Case of the Mekong Delta, Vietnam
}

\author{
Andrea Zinzani \\ Global Development Institute, University of Manchester, Manchester M13 9PL, UK; \\ andrea.zinzani@manchester.ac.uk or andrea.zinzani@gmail.com
}

Received: 14 December 2017; Accepted: 22 January 2018; Published: 26 January 2018

\begin{abstract}
Over the last few decades, coastalscapes have been seriously threatened by the rising effects of climate change such as sea level rise, coastal degradation and extreme flooding. To cope with these threats, since 1992, international development organisations have promoted Integrated Coastal Zone Management (ICZM) and its implementation in particular in coastal regions of the "Global South". Inspired by a political ecology of development approach, this paper analyses coastalscape metabolism and community level socio-environmental transformations in relation to ICZM implementation politics in the Mekong Delta, Vietnam. ICZM was designed to integrate management of coastal regions and to promote socio-economic and environmental sustainability. By adopting the concept of metabolism to coastalscapes, and reflecting on their interactions, data were collected through qualitative field-research at the community level in the Mekong Delta. Research shows that ICZM and its development initiatives implementation slightly shaped coastalscape governance and communities relations, merely influencing policy-making and state bureaucratic structure and legitimation. Rather, the Mekong Delta coastalscape was reconfigured by complex metabolic socio-environmental transformations which embed global political-economic processes, shifting water flows and climate change dynamics.
\end{abstract}

Keywords: international development; ICZM; metabolism; coastalscape; Mekong delta; Vietnam

\section{Introduction}

In the context of society-environment interactions, transformations in rivers, deltas and coastal zones management play a key role in territorialisation processes and community level socio-environmental relations, as well as in politics of state-building and power consolidation (Smith 1984; Bryant 1991; Robbins 2004). Over the last two decades, in the context of the rise of global governance and discourses on the environment related to dynamics of climate change, international development organisations and experts have designed global policies to promote socio-economic and environmental sustainability. Particularly in the "Global South", many international blueprints and initiatives aimed at improving land, water or coastal governance, were promoted in the pathway towards sustainable development (Ferguson 1990; Swyngedouw 2004; Biswas 2008). However, as many critical scholars such as geographers and political ecologists point out, behind the support for sustainable development, development organisations often depoliticised their initiatives and related narratives, hiding their political nature and the contested politics and social changes that their implementation implies (Escobar 1995; Bakker 2003; Budds and Sultana 2013). It should be argued that these development initiatives often supported neoliberalisation, global capital networks and related objectives in the transformation of society-environment relations.

Among these policies, and focusing on coastalscapes, the ICZM framework has been developed since the early 1990s by international experts and policy-makers for marine and coastal planning, and the promotion of integrated management of coastal and marine ecosystem to achieve 
socio-environmental sustainability (Christie 2005; O'Hagan and Ballinger 2010). Over the last two decades, many initiatives have been designed and sponsored to globally implement ICZM and promote coastal socio-environmental protection from the threats of climate change and environmental degradation. However, this specific context of political transformations poses relevant unanswered questions with regard to interactions between international development policies, the state and coastal communities in terms of policy making, governance, practices and socio-power transformations. Whereas a growing body of literature in political ecology recognised the need of a critical approach to international development policies and their socio-power related reconfigurations, a lack of research emerges on coastal regions, their communities and related transformations. Furthermore, the concept of metabolism, debated since almost two decades to explore socio-natural flows and transformations in diverse contexts, has not been adopted yet to analyse coastalscapes. Metabolism, defined as a interdependent and complex set of socio-power, natural and bio-physical interactions (Foster 1999; Swyngedouw 2004; Moore 2011) is relevant to explore and deconstruct socio-natural transformations in complex environments such as coastalscapes.

By advancing the scholarship on the Political Ecology of Development, this paper aims to analyse coastalscape metabolism and community level socio-environmental transformations in relation to ICZM implementation politics in the Mekong Delta, Vietnam. Specifically, it seeks to explore how ICZM initiatives, promoted by development organisations and the state, has shaped coastalscape and the related communities' socio-environmental metabolic transformations. Vietnam, and especially the Mekong Delta, has been facing significant socio-environmental issues related to the rising effects of climate change such as land and coastal degradation, mangrove forests deterioration and sea level rise (Molle et al. 2009; Genschick 2014). In parallel, since the 1990s, the Vietnamese political system, although characterised by the key role of the state guided by Marxist-Leninist principles, has introduced reforms oriented towards resources management decentralisation and progressive liberalisation (Benedikter 2014; Evers and Benedikter 2009; Cuong and Cu 2014). To deal with these socio-environmental issues, the government formalised ICZM through the support of the governments of the Netherlands and of Australia, the Vietnam-Netherlands ICZM project and the World Bank (WB) among others. Furthermore, the German Corporation for International Cooperation (GIZ), AustralianAid and the WB recently promoted blueprints in some province of the Mekong Delta to support ICZM at the community level (GIZ 2014).

To analyse these processes, with regard to the methodology, data were collected through a qualitative ethnographic and multi-scalar approach in the Mekong Delta coastalscape which will be explained in details afterwards. The Introduction is followed by Section 2 which situates research in the scholarship on the Political Ecology of Development, while discussing development and socio-power interactions. Moreover, Section 2 presents the concept of metabolism, highlighting the need to adopt the concept to coastalscapes. Section 3 presents ICZM, its rationale and objectives as a global policy, while Section 4 discusses its implementation, together with related international development initiatives in Vietnam. Section 5 explores the Mekong Delta coastalscape, presents the methodology, reflects on its challenges and sheds light on community socio-environmental transformations in the three selected case-studies. The Discussion and Conclusions Sections provide a detailed analysis and a critical reflection on coastalscape metabolic transformations in relation to ICZM and its initiatives.

\section{Political Ecology, Metabolism and Their Adoption to Coastalscapes}

For almost three decades, the scholarship on Political Ecology has provided a relevant contribution to the reconceptualisation of environment-society interactions by critically analysing environmental politics and governance, and related socio-environmental challenges (Bryant 1991; Bakker 2003; Swyngedouw 2004; Robbins 2004). Through the adoption of critical neo-Marxist theories to disentangle interfaces between the society and the environment, scholars critically explored power and socio-political dimensions of environmental governance by reflecting on neoliberal capitalism, nature and resources interfaces (Escobar 1995; Swyngedouw 2004; Kaika 2006). Debating these 
processes, they highlighted the centrality of global capital power in shaping society-environment interactions and the interconnected issues of socio-environmental inequalities, (un)justice and conflicts in relation with resources property regimes and access (Perreault et al. 2015). Furthermore, the Political Ecology approach has concentrated on the analysis of these processes at multiple scales, paying attention at the community level and its socio-power transformations by the adoption of qualitative ethnographic methodologies.

In parallel, by linking these processes with international development initiatives, the branch of the Political Ecology of Development, influenced by critical and post-development studies (Escobar 1995; Adger et al. 2001), seeks at critically analysing role and aims of international development organisations, the political nature and logics of their initiatives in opposition to the depoliticisation of environmental politics (Swyngedouw 2004; Budds and Sultana 2013; Zinzani 2018). Moreover, it explores how the adoption and implementation of development initiatives impact and affect socio-power relations within the society in regions of the "Global South", by focusing on resources governance, related knowledge and practices, and socio-environmental tensions (Loftus 2009; Budds and Hinojosa 2012; Zinzani 2015). With regard to the reconfiguration of governance and property regimes, development organisations and policy-makers advanced and often supported the concept of good governance, characterised by a reduction of the role of the state, the involvement of private investors, as well as the promotion of participatory approaches (GIZ 2014; UNEP 2016). In relation to the politics of development organisations in the reconfiguration of governance, the question of shifting property rights regimes, often driven by liberalisation and privatisation processes, was highly contested. In parallel, the role and struggles of NGOs, social movements and communities to control decisions regarding resources development within their territories were emphasised (Himley 2008; Blühdorn 2013; Bakker 2013).

By focusing on coastal regions, Milligan and O'riordan (2007), Bremer and Glavovic (2013), and Fletcher et al. (2014) argued that coastal governance should include the whole range of actors such as the state, civil society and communities and their diverse logics and interests which shape management, development and protection of the coastal environment. Whereas these processes were debated by policy-makers and academics mostly through the framework of coastal good governance and solutions to deal with climate change dynamics, few research adopted a Political Ecology approach in the analysis of coastal governance and socio-environmental issues (Hall 2003; Armitage and Tam 2007; Barton and Fløysand 2010; Lukas 2014). Therefore, by providing a novel contribution, this paper adopts to coastal governance and transformation processes the concept of metabolism together with the notion of coastalscape.

The metabolism, applied to social sciences, was advanced by Marx to analyse dynamic internal relationships between humans and nature. Marx developed the concept to describe the complex and interdependent set of needs and relations brought into being and reproduced through the organisation of labour driven by knowledge, structures and capital flows (Foster 1999; Pincetl et al. 2012). By linking these processes with nature, metabolism took on both a specific ecological meaning and a wider social meaning. The concept was recently reconceptualised by Marxist and post-Marxist theorists who critically debated relations between capital accumulation and the environment, their metabolic transformations, and the ecologic crisis (Foster 1999; Clark and Foster 2010; Moore 2011). Over the last decade, the concept has been adopted by political ecologists to disentangle socio-physical transformations related to political processes, power dynamics and capital accumulation, as well as to bio-physical and social flows. Swyngedouw (2004) defined metabolism as the process of contiguous de-territorialisation and re-territorialisation through metabolic flows organised through socio-power and physical conduits. These metabolic flows refer to the merging of bio-physical dynamics with processes that frame social relations of production and power dynamics in a territorial space. Its diverse applications in Political Ecology shed light on the one hand on how specific territorial transformations are produced through socio-ecologic and political processes (Heynen et al. 2006). On the other hand, as argued by Martinez-Alier (2002) and Muradian, Walter, and Martinez-Alier (Muradian et al. 2012), metabolism was applied to explore socio-environmental conflicts at different scales. These conflicts 
arose because of inequalities in power and property among social actors while they appropriate resources or generate environmental impacts. With regard to metabolism and the scale, Pincetl, Bunje, and Holmes (Pincetl et al. 2012) stated that metabolism, by referring to urban contexts, is situated in a nested system that is interconnected, interactive and interdependent. In addition, it is characterised by multi-scalar dynamics which range on the one hand from the global to the local level, while on the other hand from global climate change to the political economy of an urban district. Indeed, the metabolism was often applied to urbanscapes, in particular to analyse how the reconfiguration of urban politics and infrastructural projects transforms specific urban spaces and their different physical and power realities (Swyngedouw and Heynen 2003; Heynen et al. 2006; Heynen 2014). Therefore, the adoption of metabolism to coastalscapes represents a novel approach and fills a research gap. Moreover, it is relevant since coastalscapes, in particular in the "Global South", are shaped by multi-scalar processes which range from ICZM implementation politics and related socio-power transformations to environmental and climate change events.

This paper advances also the notion of coastalscape, which is drawn on waterscape, a concept widely debated over the last decades by scholars in the Political Ecology of Water (Loftus 2006; Harris and Alatout 2010; Budds and Hinojosa 2012; Swyngedouw 2014). The coastalscape is not merely a coastal territory, but a produced socio-natural construction shaped by terrestrial and marine socio-political and environmental processes and their intersections. Indeed, it represents a socio-spatial entity characterised by the assemblage of fresh and marine water flows, infrastructures, institutions and authorities. Furthermore, the coastalscape overlaps land, water and marine policies and everyday formal and informal practices and social struggles.

\section{A Global Paradigm for Coastal Governance: Integrated Coastal Zone Management (ICZM)}

Over the last few decades, the worldwide governance of coastal regions has been guided by principles of ICZM, which attempt to shape and reconfigure existing heterogeneous norms and practices of coastal management and protection. ICZM, as briefly described in the introduction, was discussed and designed by international policy-makers, experts and members of international organisations in 1992 during the Earth Summit of Rio de Janeiro. Later on, it was formalised in the framework of global environmental policies designed to promote sustainable development and deal with climate change. At that time, the Intergovernmental Panel on Climate Change (IPCC), as well as the World Commission on the Environment and Development (UNEP), were already aware of the fact that coastal regions would have been seriously threatened by the rising dynamics of climate change such as the intensification of extreme rainfalls and flooding, coastal degradation as well as sea level rise due to glaciers melting. These dynamics, as recent events globally showed, have serious impacts on coastalscapes and their communities.

ICZM was defined by the UNEP (2016) as an adaptive multi-sectoral governance approach which strives to balance development, use and protection of coastal environments. Cicin-Sain and Belfiore (2005) provided a more detailed definition, arguing that ICZM is a process by which rational decisions are made concerning the conservation and sustainable use of coastal and ocean resources. The process is designed to overcome the fragmentation inherent in single-sector management approaches, in the splits in jurisdiction among different levels of government and in land-water interfaces. Christie (2005) added that ICZM is a broad and dynamic process that requires active involvement of many stakeholders with interests in how coastal resources are allocated. ICZM seeks to achieve objectives of sustainability and institutional integration and to balance coastal environmental, economic and social dimensions. With regard to sustainability, ICZM aims to support sustainable economic growth of coastalscapes, sustainable interactions of coastal and marine environments and the preservation of coastal ecosystems. Concerning integration, ICZM seeks to formalise cross-sectoral integration, institutional integration between multi-scale levels of government and territorial integration between neighbouring territories and states. With regard to the social dimension, ICZM aims to promote an open, horizontal and participatory approach in decision-making processes which should include all stakeholders. 
If we reflect on contents and aims of the ICZM framework, it seems that its implementation has high potential to improve coastal management and protection, benefit communities and all stakeholders and to strengthen sustainability and growth according to a win-win strategy. Nevertheless, ICZM was depoliticised (Swyngedouw 2011; Schulz and Siriwardane 2015) since it hides its political nature and it does not consider issues of power asymmetries, uneven relations, the conflicting nature of divergent economic interests as well as rescaling processes and those of resources access. Moreover, ICZM adopts concepts such as integration, sustainability and participation which were not adequately analysed in relation to reconfigurations promoted by the framework implementation. For instance, relations between sustainability, environmental protection and economic growth was debated and criticised by many critical social scientists due to its conflicting and contradictory nature (Adger et al. 2001; Cornwall and Brock 2005; Blühdorn 2013). Nevertheless, over the last two decades, ICZM and its implementation process has been criticised by many scholars which highlighted and discussed diverse issues such as the complexities of institutional transformations, politics and participation, as well as issues of coastal and marine borders and scalar reconfigurations (Nichols 1999; Christie 2005; Ballinger et al. 2010b).

With regard to institutional transformations in coastal India, Ramesh and Vel (2011) argued that the ICZM implementation was quite problematic due to institutional rescaling issues and lack of integration between state governments. Conversely, by focusing on participation, evidence from Vietnam showed that the government, embedded in a top-down tradition, demonstrated a great reluctance for change concerning the introduction of participatory approaches in ICZM decision-making processes (Abelshausen et al. 2015). While Nichols (1999), by focusing on Sri Lanka, argued that the ICZM implementation facilitated the opening of coastal zones worldwide to aggressive global capital investments and resources commodification. The author added that ICZM threatened the existence of sustainable examples of resources common property regimes managed by coastal communities. Whereas ICZM and its implementation was debated and criticised adopting diverse perspectives, few studies explored how its implementation might shape coastalscape communities and their socio-environmental relations. Furthermore, the framework, in relation to coastalscape metabolic transformations, was never analysed through the lens of Political Ecology, and therefore it is relevant.

\section{ICZM Implementation in Vietnam and Its Coastalscapes}

The intervention of international development organisations in Vietnam through the support of development initiatives, ICZM among them, has initiated since the 1990s, when the government started to launch reforms oriented towards a gradual national economic liberalisation. It is relevant to highlight that since 1976 Vietnam has become a socialist people's republic characterised by a Marxist-Leninist political system culturally influenced by Confucianism, and guided by its Communist Party. Whereas since the 1990s institutional reforms oriented towards market economy and the liberalisation of national economic sectors have been introduced, the state and its leading party still have a predominant role in the political, social and economic spheres (Lebel et al. 2005; Molle et al. 2009). Vietnam's political system was diversely defined by experts and scholars "market oriented socialism", "democratic centralism" and "modern bureaucratic regime" due to the combination of a socialist ideology, a strong bureaucratic structure and a semi-market economy (Waibel 2010; Benedikter 2014). With regard to Vietnam's coastalscape, the country is characterised by a coastline which extends $3440 \mathrm{~km}$ from the Chinese border in the North to the frontier with Cambodia in the South and it is featured by a tropical humid climate with abundant rainfall (Sekhar 2005). Over the last two decades, Vietnam's coastalscape has been characterised by a relevant increase of population, migrations from internal areas to the coastline and urbanisation processes as well as economic development, foreign development projects and pollution. These processes severely caused coastal and ecosystem degradation. To deal with these issues and play an active role in the socio-economic development of Vietnam, international development organisations, in collaboration with the government, fostered ICZM implementation. 
At the national level, ICZM has been promoted since the 2000s by governments of the Netherlands and Australia together with the WB, the United Nations Development Programme (UNDP) and the GIZ (Cuong and Cu 2014; Abelshausen et al. 2015). At that time, ICZM was not officially formalised by a new national legislation, but rather promoted through the design of international projects and pilot initiatives inspired by the framework. Thanks to the support of the government of the Netherlands and the WB, since 2005 the Vietnam-Netherlands ICZM program (VNICZM) was promoted at the national and province levels through the design of three pilot projects in the northern coastline. VNICZM aimed at advising the government in coastal resources and communities management in a sustainable way; depending on the case-study, management focused on infrastructural, industrial and tourism development. Sekhar (2005) stated that the program showed a quite effective implementation in the case study areas, demonstrated by an increased institutional cooperation between authorities and an increase of awareness regarding coastal protection. Whereas Sekhar emphasised the persistence of a fragmented sectoral management and a weak participation of community level stakeholders, a reflection on how coastalscapes might have been shaped in social and environmental terms was not provided. With regard to institutional transformations and actors involved in the decision-making process, the VNICZM supported the creation of the new Ministry of the Environment and Natural Resources (MONRE), and its Agency of Sea and Islands among others, which was established thanks to foreign aid. The aims behind the establishment of a new Ministry were oriented towards the facilitation of the program development and policy-making as well as to raise awareness on environmental issues. However, the creation of a new state authority, instead of facilitating the process, led to bureaucratic competition with the existing Ministry of Agriculture and Rural Development (MARD), and in particular with the Directorate of Fisheries due to unclear differentiation of functions. Indeed, until this institutional reconfiguration, MARD was the unique governmental actor involved with territorial and coastal management processes. By reflecting on the socio-political and economic transformations linked to ICZM projects in Vietnam, An, Phung, and Chau (An et al. 2008) highlighted contradictory processes: on the one hand they stressed the importance of sustainability for the future of coastal regions, while on the other hand they remarked that pressure for ICZM establishment was related to the development of marine economy through the use of unexploited marine resources. Furthermore, it was also argued that participation in decision-making processes was encouraged to change behaviour and mentality of community members and to deliver incentives according to market mechanisms. Indeed, by referring to relations between international actors, the government and ICZM, it is relevant to highlight that international development organisations and foreign governments supported the framework implementation also with the attempt of opening spaces for economic decentralisation and foreign investors beyond the role of the state. However, the state took the opportunity to strengthen its bureaucratic structure through the establishment of the new Ministry (MONRE) and to get a stronger legitimation in terms of environmental issues.

To strengthen the development pathway towards ICZM and make the Mekong Delta more resilient against climate change, since 2011, GIZ, in collaboration with AustralianAid, launched the Integrated Coastal Management Programme (ICMP). Articulated in two phases, 2011-2014 and 2015-2018, it has been implemented in five provinces of the Mekong Delta which are Soc Trang, Bac Lieu, Ca Mau, Kien Giang and An Giang (GIZ 2014). Based on the integration principle, the ICMP focuses on diverse dimensions of coastal management such as: Area Management, which includes the establishment of breakwater fences, mangrove forests rehabilitation and their co-management; Sustainable Livelihoods, which includes the promotion of new sustainable techniques and practices for agriculture and aquaculture; Environmental Awareness, in particular at the community level; and Coastal Governance, with the aim of turning local solutions into national policies (GIZ 2014). With regard to participation and social transformations in coastal resources management, as discussed also by Abelshausen, Vanwing, and Jacquet (Abelshausen et al. 2015), co-management is based on a system of shared governance between coastal communities, who share forest resources and do aquaculture, and the state, who owns forests. Although development organisations presented 
this approach as sustainable, participatory and innovative for mangrove forests protection, they did not consider how it could rework former community level practices in diverse settings and forms of knowledge, social relations, and community level state-farmers relations. For instance, forms of participation and community resources management were already formalised in 1998 through the Grassroots Democracy Decree, and the Decree on Resources Users Groups (2007) which led to the establishment of agriculture, aquaculture, fisheries associations and corporations (Evers and Benedikter 2009). In addition to participatory approaches, a lack of critical reflection emerged on the payment for environmental services, which members of development organisations presented as a success factor for co-management without taking into consideration its socio-economic impact and existing practices at the community level. These development initiatives, combined with the involvement of the government and ministries (MONRE and MARD), enabled the strengthening of the ICZM national level institutional structure.

Indeed, since 2015, MONRE and GIZ launched the Vietnam's strategy for ICZM to 2020 and vision towards 2030 that was approved by the Prime Minister. The strategy aims at sustainable economic and social development by protecting coastal natural resource and the environment in the long-term through a strategic process. The process has to combine new legislations and training for capacity development, sustainable exploitation of natural resources together with preservation of nature, and control against climate change and sea level rise. The Vietnamese government stated that the objective of the strategy by 2020 and the vision by 2030 is that coastal region in Vietnam are, and will be, clean, nice, and safe to live, work, and make investments (Hoi and Hien 2014). According to the evidence emerged from international development initiatives and national institutional structure, the pathway to the implementation of ICZM seems to be a long and complex process. In relation to this process and its challenges, the next section analyses coastalscape metabolic transformations in relation to the implementation pathway towards ICZM in the Mekong Delta.

\section{ICZM Implementation Pathway and Coastalscape Metabolic Transformations in the Mekong Delta}

\subsection{Methodology, the Mekong Coastalscape and Its Governance}

Since ancient times, the Mekong Delta has been produced and developed by a combination of socio-natural and political processes, infrastructural development, diverse political orders, power relations and forms of knowledge inspired by the logic of the social control of nature and specifically by the hydraulic mission (Biggs et al. 2009; Evers and Benedikter 2009; Molle et al. 2009). Inhabited by approximately 18 million people and characterised by an extensive network of canals, dykes and water fences and by a combination of metabolic relations of agriculture and aquaculture farms, the Mekong Delta is the result of a complex process of land and sea, and fresh, salty and brackish water interactions (Figure 1). Indeed, the coastalscape has been recently seriously threatened by sea level rise, coastal erosion and mangrove forests degradation together with soils salinisation due to drought and lack of freshwater (GIZ 2015). It is relevant to state that in relation with these interdependent processes, over the last decades the Mekong coastalscape has been affected by a relevant reduction of agricultural land and a boom in aquaculture, as deeply analysed by Islam (2014) in other South Asian regions. 


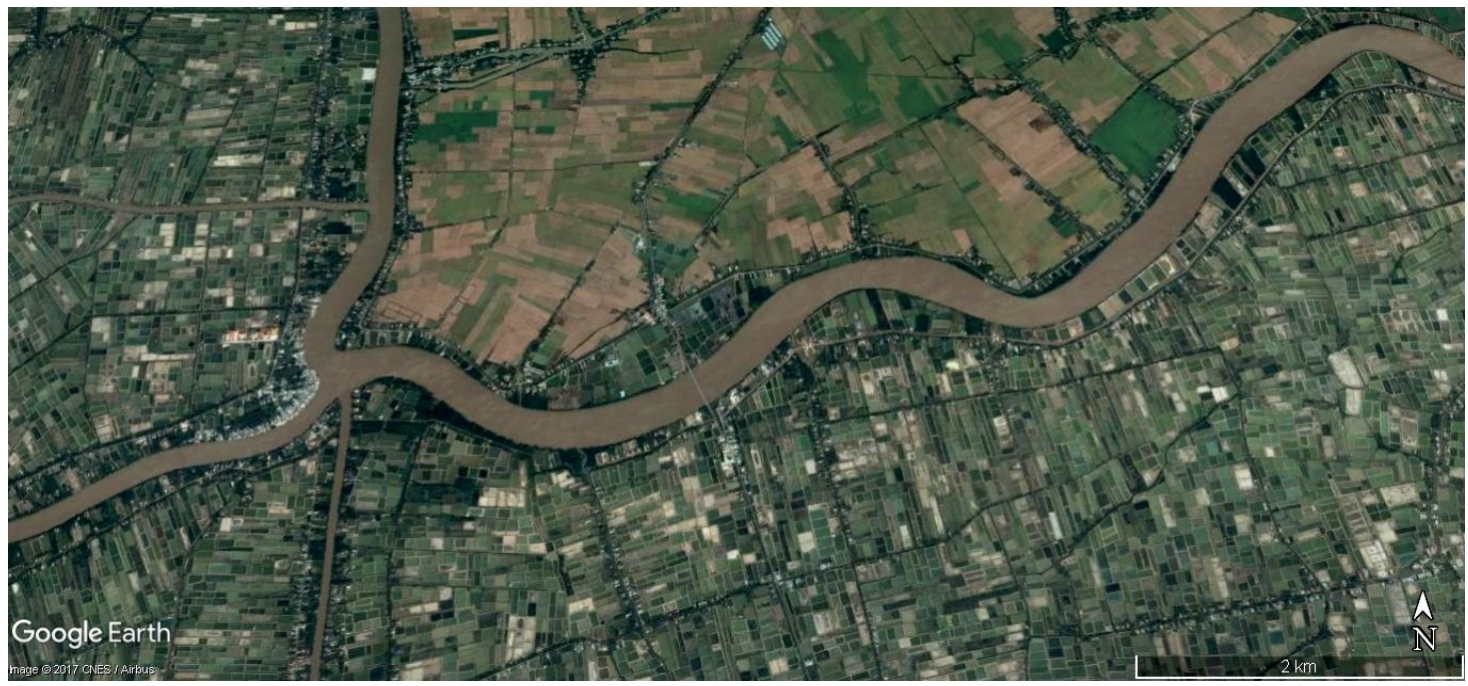

Figure 1. Satellite image (Google Earth ${ }^{\mathrm{TM}}$ ) which represents the Mekong Delta coastalscape (Vin Chau district) and its territorial complexity characterised by agriculture and aquaculture.

With the aim at analysing coastalscape metabolic transformations and community level socio-environmental changes in relation to the implementation of ICZM initiatives in the Mekong Delta, a qualitative ethnographic approach was applied. To explore these processes according to a multi-scalar approach, three provinces (Soc Trang, Ca Mau, and Trah Vinh), three districts (Vin Chau, Tran Van Thoi and Cau Ngang) and three communes (Vin Hai, Song Doc and My Long) were selected (Figure 2). These administrative units were chosen due to their territorial characteristics with the aim to have a deep overview of the heterogeneity of the Mekong Delta coastalscape and of the development context. Indeed, two of the three selected provinces were included in the ICMP, while one not, and this condition might be important in the understanding of diversities in the ICZM awareness and implementation.



Figure 2. GIS Elaboration of a satellite image (Google Earth ${ }^{\mathrm{TM}}$ ) representing the Mekong Delta and field-research case study areas. Shapes represent the districts where selected communes are located. 
Field-research was conducted between May and June 2016 and supported by the Department of Water Resources of the University of Can Tho. The methodology was based firstly on semi-structured interviews with members of state authorities and institutions involved in coastal governance processes and the implementation of ICZM such as MARD (Directorates of Irrigation and Fisheries) and MONRE (Agencies of Sea and Islands, and Water Resources) at province and district levels (named DARD and DONRE). Furthermore, interviews were conducted with members of local authorities such as communes and villages. Secondly, semi-structured and open interviews, meetings and informal talks were conducted with farmers involved with agriculture and aquaculture, and members of their associations, as well as with community members and individuals in the selected communes. In total, 17 semi-structured interviews were conducted with members of state authorities at national, province and district levels and experts. Respondents were selected by their own institutions. At the community level, approximately 40 individuals were interviewed or contacted through both formal and informal practices. Individuals were selected through a network of contacts of members of local communes, adopting a snowball effect and also randomly. By reflecting on the concept of metabolism, research focused on the role of institutions, territorial transformations, community level socio-environmental changes, dynamics and practices of coastal governance. In addition, field surveys and observations of the coastalscape, its environment and infrastructures (mangrove forests, dykes and sea fences) were carried out. Nevertheless, it is important to highlight that ethnographic research and data collection process was quite challenging and difficult because of the pervasive control of Vietnamese state authorities, due to the sensitivity of research topics and of the analysis of socio-political process in general. State authorities, in collaboration with the host institution, designed a research schedule of required meetings and interviews with members of ministries and authorities. Concerning field-research at the community level, province and district authorities influenced and in certain cases hampered visits and access to some strategic selected areas, while, in addition, part of interviews and meetings were supervised by members of communes or of security services. Whereas on the one hand this context represented an issue for the development of field-research, on the other hand it also enabled a deep reflection on controversial coastalscape socio-political dynamics which emerged during research, and on the role of state authorities as knowledge gatekeepers. Collected data analysis was characterised firstly by an open coding for categorising collected data and for identifying specific common dynamics, processes, issues, ideas and narratives. Secondly, a deep analysis was conducted on processes, dynamics, relations and interactions which emerged from the open coding, and a reflection was carried out on the evidence.

Initial discussions with members of both MARD and MONRE, the two main Vietnamese institutions involved in coastal governance, enabled the understanding of the official Vietnamese vision of the notion of coastal region. According to the national legislation, coastal regions include on the land side the territory of coastal communes, and hence they are based on administrative principles and institutional boundaries. On the sea side, coastal regions include three miles of seawater. By focusing on their territorial nature, they are characterised by diverse socio-natural environments: mangrove forests, which extend to the majority of the Mekong Delta coastline, play a key role in preventing coastal erosion and in protecting lands from flooding. Beyond the forest, whose width range approximately from $20 \mathrm{~m}$ to more than one kilometre, since the 1980s a coastal dyke has been built to strengthen the protection of fields, ponds and villages (Nguyen and Evers 2011). Beyond the dyke, the coastalscape is characterised by an heterogeneous patchwork of small villages, household plots and rice fields, ponds for crabs and shrimps aquaculture and a network of Mekong river's stream and canals. The network is featured by a complex system of dykes, sluices and gates which regulate water flow from upstream and canals' mouths, and separate fresh from brackish and salty waters. Therefore, rice fields irrigated from streams and freshwater canals, and aquaculture ponds filled with brackish and salty water represent the liquid and shifting territorial entities which characterise the Mekong Delta coastalscape. 
Whereas the coastalscape is today the result of metabolic transformations which combined socio-political and environmental processes and flows, and have occurred since decades, it also embeds recent governance reconfigurations which occurred in relation to the implementation of ICZM and the ICMP. By initiating with the understanding of this process, it is necessary to reflect on the notion of coastal governance and its adaptation to the Vietnamese context, and specifically to the Mekong Delta coastalscape. Moreover, to identify stakeholders, the institutional context that governs processes, flows and materialities. Therefore, members of DARD at province and district levels, questioned on dimensions of coastal governance in the Mekong Delta, argued that they include the release of fishing rights, which is under the supervision of district DARD from the coastline to 12 miles, and of province DARD beyond 12 miles; the management and maintenance of sea fences and barriers, under the joint control of DARD and DONRE at the district level; the preservation and governance of mangrove forests which include members of the province level forests department of DARD, the district office of DARD, wardens of the commune's People's Committee and individuals involved in co-management and co-management groups; the operation and maintenance of the main coastal dyke, which is controlled by the province department of DARD. Members of these authorities affirmed that this has been the coastal governance context since 2006, when MONRE and its DONRE were established. Previously, the role and functions of DONRE were mainly covered by DARD. Despite the active involvement of diverse state actors, neither institutional disputes in coastal governance between the authorities and their functions, nor tensions related to power asymmetries emerged. With regard to co-management, although it has been supported by international development organisations through the design of groups within the ICMP, as it will be discussed in the next sub-section, this practice has been already embedded in the Vietnamese natural resources management rationale. The next sub-section explores coastalscape metabolism by focusing on coastal governance and community level socio-environmental metabolic transformations in relation to ICZM in the Soc Trang, Ca Mau and Tra Vinh provinces at multiple scales.

\subsection{A Multi-Scalar Analysis of Coastalscape Metabolic Transformations: Evidence from Coastal Communities}

In the Soc Trang province, the Vin Chau district and the commune of Vin Hai were chosen to conduct field-research and the decision approved by the province People's Committee. The district includes more than the $80 \%$ of the Soc Trang province coastalscape. Whereas in the Soc Trang province agriculture, and especially rice cultivations, is conducted on approximately 350,000 hectares of land while aquaculture on 70,000 hectares, in Vin Chau district the vast majority of land is used for aquaculture. By reflecting on the territorial nature of the coastalscape, as stated by the director of DONRE, since decades the Vin Chau district has been characterised by land-sea interactions and surrounded by brackish and salty waters streams and canals. The head of the Vin Hai commune added that household plots and small-scale rice agriculture mostly use groundwater since freshwater flow from the Mekong river has significantly reduced over the last two decades. They both argued that, since the 2000s, rising dynamics of climate change such as drought, reduction of fresh water, brackish and salinity water intrusion, deeply shaped the coastalscape and their communities. These dynamics led to issue in conducting small scale and rice farming due to lack of fresh water and soils salinisation, and therefore a significant increase in conducting aquaculture occurred. Members of DARD and DONRE at district and province levels confirmed that aquaculture was supported by the government due to incentives of development organisations and to the possibility for farmers to get higher income. With regard to community level socio-power relations, this reconfiguration did not lead to tensions in terms of land use and resources access due to the physical separation and resources differentiation between aquaculture, connected to brackish waters, and small plots, irrigated with groundwater. However, farmers in Vin Hai stated that over the last years members of the community have left small-scale agriculture to develop aquaculture and this reconfiguration was problematic due to knowledge and practices transformations. Farmers also highlighted the rise of social differentiation together with growing inequalities. Other members of the Vin Hai commune stated that at the end of 
the 1990s portions of mangrove forests were reconfigured into aquaculture ponds. This socio-natural transformation was also supported by the rise of power of international shrimps trade companies, who played a key role in debated and contradictory "Blue Revolution", as argued by Islam (2014). It is relevant to highlight that aside aquaculture and small-scale agriculture, fishery is almost not conducted due to the mangrove forest coastal belt and the absence of ports.

By reflecting on ICZM implementation in relation to the community level, members of the district DARD and the Vin Hai commune argued that since a decade DARD and DONRE have strengthened integrated coastal governance and that the commune, and specifically the mangrove forest management, has been included in the ICMP. Indeed, since 2011, in the framework of the ICMP, the sponsorship of co-management initiatives and the creation of co-management groups have been supported by GIZ with the aim to strengthen participation, mangrove forest sustainable use, conservation and protection, and increase environmental awareness. Through the support and the control of commune's authorities, six co-management groups were established and mangrove forest use for aquaculture was regulated according to diverse degrees of protection. Interviewed farmers, members of co-management groups, stated that this initiative enabled them to be involved in active decision-making processes and to contribute to mangrove forest protection against the rising effect of climate change such as coastal erosion and degradation. However, they argued that the introduction of environmental fees in co-management, promoted by international organisations as a questionable economic initiative to support forests conservations, was quite problematic due to members' unwillingness to pay and lack of funds. Other members of the Vin Hai commune, the majority of them aquaculture farmers, stated that co-management groups designed within ICMP involved only the $30 \%$ of households, especially those living close to the forest and the dyke. In addition, they argued that forms of co-management between commune's authorities and farmers, and informal practices for forests management, already existed. Indeed, as stated by the head of the Vin Hai commune, the principle of co-management has been supported by the Vietnamese state as a process to strengthen state-society relations, especially with local communities. Farmers added that over the last few years, members of district level DONRE, DARD and Vin Hai commune have co-organised meetings and seminars to increase community's awareness on ICZM, environmental conservation and the threats of climate change.

However, by reflecting on coastalscape transformations and climate change, the evidence from the Vin Hai commune showed that over the last decade members of the coastal community have been affected by landslides of canals' banks. According to members interviewed, since 2006 affected people have been resettled approximately $30 \mathrm{~km}$ away in a new settlement through a government plan of the Soc Trang province. Even though, at that time resettled people received an house and a pond to conduct aquaculture, after few years the majority of them stopped this activity due to knowledge, technical and financial issues and low income, and today they are unemployed. This context led to social exclusion issues and, as resettled people stated, they were forgotten by local authorities. This process was almost hidden by both members of the Vin Hai commune and those of Vin Chau district DARD and DONRE. Therefore, it emerges how the problematic socio-environmental issues of resettled communities were abandoned by authorities and neither considered by international development organisations.

Similar issues emerged also in the Ca Mau province, specifically in the Song Doc commune of the Tran Van Thoi district which was chosen as field-research area. With regard to field-research issues, despite the choice was approved by the province People's Committee, commune's authorities denied access and permission to conduct research in some strategic areas. By reflecting on the territorial nature, as highlighted by members of province level DARD, the Ca Mau province and the Tran Van Thoi district are characterised by a complex system of brackish and salty water stream and canals linked to the sea and regulated by hydraulic infrastructures such as gates and sluices. Due to its position in the southernmost Mekong Delta, the Ca Mau province does not receive water flow from the river, and this condition represents an issue of lack of freshwater. The head of the district DONRE argued 
that despite rice agriculture is still conducted in the northern part of the district due to rainwater storage and the protection from salty water by new automatic gates, aquaculture is becoming the predominant socio-economic activity. Moreover, by reflecting on the coastalscape transformations, the head of the district DARD stated that, since the end of the 1990s, a territorial reconfiguration has occurred, in particular in the southern part of the district, through a relevant shift from agriculture to aquaculture or to a combination of both socio-economic practices. The transformation, formalised through a five years government plan, was characterised on the one hand by farmers associations and cooperatives' demand for higher income, while on the other hand by climate change dynamics. Indeed, both heads of district DARD and DONRE argued that drought, soils salinisation and salinity intrusion played a significant role in these transformations, despite the economic nature of the process has been recognised globally (Tiller et al. 2013; Islam 2014). Concerning the ICZM implementation, despite the Ca Mau province is officially included in the ICMP, heads of Tran Van Thoi district authorities, both DARD and DONRE, were not aware of the Programme, and neither of ICZM. They heard from members of the province DARD that the WB and the GIZ were supporting the establishment of sea fences for coastal protection in a northern district. In addition, they stated that the coastline, and specifically the mangrove forest management and conservation and the coastal dyke restructuring, is managed exclusively by province DARD.

In the Song Doc commune coastalscape a quite distinct socio-economic and territorial fragmentation emerged between fisheries and aquaculture. As argued by the head of Song Doc hamlet 9, and remarked by aquaculture farmers, people living in Song Doc are fishermen, due to the presence of the port and the lack of land, while people living in neighbouring hamlets work in shrimps aquaculture. Due to this distinction in territorial and socio-economic practices, tensions in resources or land access between fishermen and aquaculture farmers, or differences in power and negotiations at the commune level, have not emerged. In addition, both groups, for two decades, have organised in cooperatives and associations which cooperate with the commune's People's Committee. However, some of aquaculture farmers highlighted threats of climate change, arguing that over the last years excessive water salinisation has affected shrimps production. Others argued that despite they are able to control the water flow from the canal to their pond, the level of canals' water increased and that it is related to sea level rise and coastal degradation.

By reflecting on the ICZM implementation at the community level, both head of the hamlet and farmers were not aware of the framework and neither of development programmes on coastal protection. Focusing on mangrove forests, according to the head of the hamlet forms of informal co-management between the forest department of DARD and local wardens enabled its protection and conservation. However, he was not aware of international development initiatives supporting diverse practices of co-management. He added that members of the district level DARD were working to increase communities' awareness of coastal degradation, protection and climate change. The restructuring of the coastal dyke, mentioned by the head of district DARD, is relevant for coastal protection as well as to understand coastalscape social transformations. Indeed, farmers told that the dyke restructuring is going to lead to a resettlement process of people living in the nearby, and it seemed to be a quite problematic and contested process. Possible social tensions with regard to resettlement process could be linked to the fact that research in the area was denied by the commune's People's Committee without providing an explanatory reason. Only a short visit, accompanied by their members, enabled the understanding of the dyke reconstruction plan which will imply the resettlement of diverse family houses and plots.

Research allowance issues occurred also in the Tra Vinh province and in particular in the selected My Long commune of the Cau Ngang district. Unlike the other case-studies, this region was not included in the ICMP. Nevertheless, with regard to the national ICZM implementation process, only members of Tra Vinh province DARD were aware of the framework, although they were not of international development programs on coastalscapes in the region. Over the last two decades, the Tra Vinh province has also been threatened by the effects of climate change: since 2000, many new 
water gates were installed to protect rice agriculture in the northern part of the province from salty water intrusion, which reached 60 kilometres inland due to El Nino effects. The head of province DARD argued that aquaculture significantly increased in the province, as occurred in those of Soc Trang and $\mathrm{Ca} \mathrm{Mau,} \mathrm{in} \mathrm{particular} \mathrm{in} \mathrm{its} \mathrm{southern} \mathrm{and} \mathrm{central} \mathrm{sections.} \mathrm{The} \mathrm{coastalscape} \mathrm{transformation}$ process was confirmed by the head of Cau Ngang district DONRE, who stated that aquaculture was introduced in the area since 2006 as a new practice or combined with agriculture, due to the progressive reduction of freshwater availability, drought and the subsequent demands of farmers. A five years government plan, based on community level demands and on climate change adaptation, was issued. The head of district DARD argued that land use reconfiguration was assisted through their water supply control and intensive training and governmental support to farmers. Members of community and farmers associations of Cau Ngang and My Long stated that this support in the complex socio-environmental transformations prevented social tensions between agriculture and aquaculture farmers and their associations. Nevertheless, they remarked that social differentiations and inequalities, due to diverse and uneven access to international shrimps markets, increased. The shift from agriculture to aquaculture occurred after 2006 but some farmers already started in previous years due to lack of fresh water and the willingness to increase their income. To deal with knowledge sharing and trade access issues, over the last ten years new aquaculture associations were established through the support of commune's People's Committee.

Despite climate change and its adaptation measures shaped the coastalscape socio-economic practices in recent years, a lack of awareness of the ICZM implementation by both authorities and community members emerged. The head of district DONRE emphasised the need to prevent coastal erosion through the conservation of mangrove forests, which was promote by a WB programme in the past years and recently by the government, and the restructuring of coastal dyke. While the head of DARD stated that his authority supported forms of co-management through the involvement of members of communities living nearby forests, who argued that the initiative gave to some of them the opportunity to actively contribute in mangrove forest protection as well as to raise awareness. As occurred in the Song Doc commune, in My Long coastal dyke was under reconstruction and the project seemed controversial and problematic. Although members of province and district DARD and DONRE stated that any large scale resettlement processes were scheduled, exclusively the removal of few houses located in dangerous areas, the Cau Ngang district People's Committee denied the authorisation to conduct research in the area, probably hiding social tensions and contestations.

\section{Discussion: ICZM and Coastalscape Metabolism}

Multi-scale field-research in three diverse provinces and communities of the Mekong Delta enabled the understanding of recent coastalscape socio-environmental metabolic processes in relation to the ICZM national implementation and the parallel international support to initiatives such as the ICMP. ICZM, promoted by foreign organisations through diverse programmes, was successfully embedded in the Vietnamese institutional structure, which advanced a vision towards 2020 and 2030. In addition, it enabled a bureaucratic state consolidation through the creation of a new Ministry, the MONRE. As argued also by Reis (2016), international development policies oriented towards effective good governance align well with the Vietnamese institutional system and its managerialist political culture. Moreover, state authorities took advantage of ICZM to reshape environmental discourses towards climate change awareness and to legitimise their role in coastal infrastructural development. Therefore, whereas ICZM was globally promoted and adopted mainly as a framework aimed to decentralise state control and boost private actors' role and market opportunities, in this context, the Vietnamese state was able to benefit from the process, in terms of its role and legitimation.

However, the evidence from the Mekong Delta coastalscape showed that coastal governance processes were slightly affected by ICZM and the ICMP. A non-change in coastal governance processes emerges by reflecting on the lack of reconfiguration of coastal institutional structure, actors involved, and their practices such as the administrative nature of coastal areas, fisheries 
permissions, forests, dykes and sea fences management. If we consider the ICZM implementation across scales, from the national to the province-district and community levels, the process emerges as quite complex, problematic and heterogeneous, as argued by diverse scholars (Nichols 1999; Ballinger et al. 2010a; Abelshausen et al. 2015). Moreover, the process was featured by lack of awareness and coordination between authorities at diverse scales. Although, especially in the Vin Hai commune (Soc Trang province), the ICZM inspired ICMP designed co-management groups for mangrove forest rehabilitation and the installation of sea fences for coastal protection, the programme did not deeply shape coastalscape communities' social relations and practices, since it involves exclusively a small group of households and farmers. The Environmental fee for forests livelihoods, supported by the ICMP as a mean to strengthen sustainable resources use, but perceived by communities as a strategy of commodification of nature, was not introduced. In addition, this measure was also considered problematic in socio-economic terms. With the except of this commune in Soc Trang province, it emerges that the majority of community members in Tran Van Thoi and Song Doc, and in Cau Ngang and My Long, were not aware of both ICZM and international development initiatives. Therefore, it is possible to argue that their socio-power relations and practices have neither been affected by the coastal paradigm nor by related international initiatives.

Conversely, the evidence from the three field-research areas showed that the coastalscape was transformed by a complex metabolic reconfiguration in territorial and socio-economic practices related to interconnected processes of boom in aquaculture and agricultural issues. The metabolic reconfiguration has specifically developed over the last decade. The process implied hydraulic and coastal infrastructural development in order to adapt on the one hand to decreasing freshwater flow and increasing salty water intrusion, while on the other hand to significant land use changes. With regard to the community level socio-power relations, the evidence showed that so far social tensions within communities have not emerged and been problematic, due in particular to a distinct territorial fragmentation among fisheries, aquaculture and agriculture. However, coastalscape metabolic transformations are leading to social differentiation and competition, power relations asymmetries which might let us assume a significant increase in social and economic inequalities. As highlighted also by Lebel et al. (2002), Hall (2003), Thi Thanh Vinh (2006) and Genschick (2014), by focusing on neighbouring Southeast Asian countries, the recent boom of intensive aquaculture, besides deep socio-power transformations, also led to heterogeneous environmental issues related to land degradation and pollution. This process strongly contradicts the international development support to aquaculture as a pathway towards green growth and sustainable development. Islam (2014) explained well how this aquaculture boom, supported by the global market and actors of the "Global North" are leading to socio-ecologic devastation, displacement of rural subsistence farmers and labour exploitation. Tiller et al. (2013) as well reflected on the impact of the boom in aquaculture on traditional and customary fisheries in Northern Europe, by shedding light on conflicts among stakeholders and the increase of inequalities.

By reflecting on processes, dynamics and flows within the metabolic transformations of the Mekong Delta coastalscape, a combination of key socio-natural entities such as the capital, waters and the climate significantly emerges. On the one hand, the recent expansion of the global capital in Vietnam, as advanced by Benedikter (2014) "the shift from state socialism to bureaucratic capitalism", through the rise of new market and trade networks related to intensive aquaculture, benefited and was supported by a progressive shift in availability from fresh to brackish and salty waters. On the other hand, this shift is progressing due to climate change effects such as extreme drought, soils salinisation, salty water intrusion and coastal degradation. Whereas the metabolic transformation is enabling a boom in aquaculture and higher incomes for some groups within communities, in parallel, it shapes coastal degradation and leads to resettlement policies and social marginalisation, as the evidence showed. By linking the coastalscape metabolism and its complex and uneven socio-environmental transformations to international development policies, it is relevant to highlight the conflicting and controversial interactions between development and sustainability. On the one hand, it emerged 
that the ICMP, through its initiatives, promotes coastal and forests protection, sustainable practices, environmental awareness and local communities empowerment. On the other hand, as emerged from the analysis of GIZ policy briefs, the ICMP promotes and aims to increase and strengthen international market access, industrialisation, foreign investments and business opportunities to international capital actors through the narrative "The Mekong Delta, an emerging investment destination in Vietnam" (GIZ 2015). In addition to contradictory relations among development, growth and sustainability that emerged in this context with regard to the support to aquaculture and trade networks, it is relevant to highlight how ICZM and linked initiatives were deeply depoliticised denying rising socio-environment injustice. Indeed, their political nature was hidden behind the leaf of socio-economic development, environment protection and sustainability.

\section{Conclusions}

In sum, although field-research in the Mekong Delta coastalscape was challenging, complex and in certain contexts hampered by Vietnamese authorities, who controlled data access and the understanding of their socio-political processes acting as knowledge gatekeepers, it was possible to analyse and shed light on its metabolic transformations. Coastalscape metabolism in the Mekong Delta was slightly affected by the ICZM implementation, which predominantly enabled state and bureaucratic consolidation at the national level. Rather, it was shaped by socio-economic and environmental processes, featured by both global and local dynamics, which embed the combined circulation of capital expansion, heterogeneous and shifting water flows, and climate change processes, leading to uneven and challenging development pathways. By reflecting on the concept of metabolism and its debates, the evidence from the Vietnamese Mekong Delta showed how coastalscapes, in addition to urbanscapes, contribute to explore metabolic transformations driven by complex socio-natural processes which include re-territorialisation, climate change dynamics and the water flow. These metabolic transformations embody and are shaped by the power of the capital expansion and the global market in the reconfiguration of socio-environmental relations and in the production of uneven socio-environmental development.

This research therefore provides to the scholarship on the Political Ecology of Development a contribution through a critical reflection on international development, metabolism and coastalscapes interactions. Specifically, through the understanding of how a coastalscape and its communities' socio-environmental transformations are shaped by multi-scalar political-economic dynamics and by the support of controversial international development policies. Further research on socio-environmental transformations in diverse contexts through the adoption of the metabolism would be relevant to strengthen and advance our understanding of inherent socio-natural relations and their diverse dimensions. In addition, a deeper understanding of reconfigurations between socio-natures, power and international development will also provide novel contributions to the concept of metabolism, as well as to the scholarship on the Political Ecology of Development.

Supplementary Materials: The following are available online at www.mdpi.com/2076-0760/7/2/19/s1. Supplementary File 1.

Acknowledgments: Research was supported by a German Academic Exchange Service (DAAD) Postdoctoral Research Grant (57130104) and by the Department of Social Sciences of the Leibniz Centre for Tropical Marine Research, ZMT, Bremen, Germany, where the author was based in 2016. Field-research in Vietnam was also supported by Tri P.D. Van, Head of the Department of Water Resources of the University of Can Tho, and by its staff. With regard to ethics, research project was approved by the DAAD, the Department of Social Sciences of the Leibniz Centre for Tropical Marine Research (ZMT) and supported by the University of Can Tho.

Conflicts of Interest: The author declares no conflict of interest. 


\section{References}

Abelshausen, Bieke, Tom Vanwing, and Wolfgang Jacquet. 2015. Participatory Integrated Coastal Zone Management in Vietnam: Theory versus Practice Case Study: Thua Thien Hue Province. Journal of Marine and Island Cultures 4: 42-53. [CrossRef]

Adger, W. Neil, Tor A. Benjaminsen, Katrina Brown, and Hanne Svarstad. 2001. Advancing a Political Ecology of Global Environmental Discourses. Development and Change 32: 681-715. [CrossRef]

An, Nguyen Tac, Nguyen Ky Phung, and Tran Bich Chau. 2008. Integrated Coastal Zone Management in Vietnam: Pattern and Perspectives. Journal of Water Resources and Environmental Engineering 23: 297-304.

Armitage, Derek, and Chui-Ling Tam. 2007. A Political Ecology of Sustainable Livelihoods in Coastal Sulawesi, Indonesia. Canadian Journal of Development Studies/Revue Canadienne D'études Du Développement 28: 39-57. [CrossRef]

Bakker, Karen. 2003. A Political Ecology of Water Privatization. Studies in Political Economy 70: 35-58. [CrossRef] Bakker, Karen. 2013. Neoliberal Versus Postneoliberal Water: Geographies of Privatization and Resistance. Annals of the Association of American Geographers 103: 253-60. [CrossRef]

Ballinger, Rhoda, A. Pickaver, G. Lymbery, and M. Ferreria. 2010a. An Evaluation of the Implementation of the European ICZM Principles. Ocean and Coastal Management 53: 738-49. [CrossRef]

Ballinger, Rhoda, Valerie Cummins, and Hance Smith. 2010b. Implementing ICZM: The Experience of Northwest Europe. Ocenan and Coastal Management 53: 725-29. [CrossRef]

Barton, Jonathan R., and Arnt Fløysand. 2010. The Political Ecology of Chilean Salmon Aquaculture, 1982-2010: A Trajectory from Economic Development to Global Sustainability. Global Environmental Change 20: 739-52. [CrossRef]

Benedikter, Simon. 2014. The Vietnamese Hydrocracy and the Mekong Delta. Berlin: LIT Verlag.

Biggs, S. D., F. Miller, C. T. Hoanh, and F. Molle. 2009. The Delta Machine: Water Management in the Mekong Delta in Historical and Contemporary Perspectives. In Contested Waterscapes in the Mekong Region: Hydropower, Livelihoods and Governance. Edited by F. Molle, T. Foran and M. Kakonen. London and New York: Routledge Earthscan, pp. 203-26.

Biswas, Asit K. 2008. Integrated Water Resources Management: Is It Working? International Journal of Water Resources Development 24: 5-22. [CrossRef]

Blühdorn, Ingolfur. 2013. The Governance of Unsustainability: Ecology and Democracy after the Post-Democratic Turn. Environmental Politics 22: 16-36. [CrossRef]

Bremer, Scott, and Bruce Glavovic. 2013. Mobilizing Knowledge for Coastal Governance Re Framing the Science Policy Interface for Integrated Coastal Management. Coastal Management 41: 39-56. [CrossRef]

Bryant, Raymond L. 1991. Putting Politics First: The Political Ecology of Sustainable Development. Global Ecology and Biogeography Letters 1: 164-66. Available online: http://www.jstor.org/stable/2997621 (accessed on 12 June 2017). [CrossRef]

Budds, Jessica, and Leonith Hinojosa. 2012. Restructuring and Rescaling Water Governance in Mining Contexts: The Co-Production of Waterscapes in Peru. Water Alternatives 5: 119-37.

Budds, Jessica, and Farhana Sultana. 2013. Guest Editorial. Environment and Planning D: Society and Space 32: 275-79. [CrossRef]

Christie, Patrick. 2005. Is Integrated Coastal Management Sustainable? Ocean E Coastal Management 48: $208-32$. [CrossRef]

Cicin-Sain, Biliana, and Stefano Belfiore. 2005. Linking Marine Protected Areas to Integrated Coastal and Ocean Management: A Review of Theory and Practice. Ocean and Coastal Management 48: 847-68. [CrossRef]

Clark, Brett, and John Bellamy Foster. 2010. Marx's Ecology in the 21st Century. World Review of Political Economy 1: 142-56. Available online: http://search.proquest.com.ezp.waldenulibrary.org/abicomplete/docview / 1021197077/abstract/143454AED1A459F4CB3/44?accountid=14872\%5Cnhttp: / / media.proquest.com.ezp. waldenulibrary.org/media/pq/classic/doc/2692194201/fmt/pi/rep/NONE?hl=capitalism,paradoxes,pa (accessed on 12 July 2017).

Cornwall, Andrea, and Karen Brock. 2005. What Do Buzzwords Do for Development Policy? A Critical Look at 'Participation', 'Empowerment' and 'Poverty Reduction'. Third World Quarterly 26: 1043-60. [CrossRef] 
Cuong, Nguyen Quoc, and Nguyen Van Cu. 2014. Integrated Coastal Management in Vietnam: Current Situation and Orientation. Journal of Marine Science and Technology 14: 89-96. Available online: http: / / www.vjs.ac.vn/index.php/jmst (accessed on 21 November 2017). [CrossRef]

Escobar, Antonio. 1995. Encountering Development: The Making and Unmaking of the Third World. Cambridge: Cambridge University Press.

Evers, Hans Dieter, and Simon Benedikter. 2009. Hydraulic Bureaucracy in a Modern Hydraulic Society—Strategic Group Formation in the Mekong Delta, Vietnam. Water Alternatives 2: 416-39.

Ferguson, James. 1990. The Anti-Politics Machine: "Development", Depoliticization and Bureaucratic Power in Lesotho. Cambridge: Cambridge University Press.

Fletcher, Stephen, Rebecca Jefferson, Gillian Glegg, Lynda Rodwell, and Wendy Dodds. 2014. England's Evolving Marine and Coastal Governance Framework. Marine Policy 45: 261-68. [CrossRef]

Foster, John Bellamy. 1999. Marx's Theory of Metabolic Rift: Classical Foundations for Environmental Sociology. American Journal of Sociology 105: 366-405. [CrossRef]

Genschick, Sven. 2014. Aqua-'Culture' Socio-Cultural Peculiarities, Practical Senses, and Missing Sustainability in Pangasius Aquaculture in the Mekong Delta, Vietnam. Berlin: LIT Verlag.

GIZ. 2014. Icmp/Cccep Phase I: Final Report. Available online: http:/ / daln.gov.vn/r/files//ICMP-CCCEP/tai_ lieu/ICMP_CCCEP_Final_Report_Phase_I.pdf (accessed on 28 October 2017).

GIZ. 2015. Integrated Coastal Management Programme. Available online: https://www.giz.de/en/worldwide/ 18661.html (accessed on 10 November 2017).

GIZ. 2015. The Mekong Delta an Emerging Investment Destination in Vietnam: Sustainable Growth, Improving Infrastructure, and an Excellent Investment Climate. Available online: http:/ / www.invest-mekong-delta. com/download/Mekong_Delta_Investment_Destination_web.pdf (accessed on 23 January 2018).

Hall, Derek. 2003. The International Political Ecology of Industrial Shrimp Aquaculture and Industrial Plantation Forestry in Southeast Asia. Journal of Southeast Asian Studies 34: 251-64. [CrossRef]

Harris, Leila M., and Samer Alatout. 2010. Negotiating Hydro-Scales, Forging States: Comparison of the Upper Tigris/Euphrates and Jordan River Basins. Political Geography 29: 148-56. [CrossRef]

Heynen, Nik. 2014. Urban Political Ecology I. Progress in Human Geography 38: 598-604. [CrossRef]

Heynen, Nik, Maria Kaika, and Erik Swyngedouw. 2006. In the Nature of Cities: Urban Political Ecology and the Politics of Urban Metabolism. London and New York: Routledge.

Himley, Matthew. 2008. Geographies of Environmental Governance: The Nexus of Nature and Neoliberalism. Geography Compass 2: 433-51. [CrossRef]

Hoi, Nguyen Chu, and Bui Thi Thu Hien. 2014. Integrated Spatial Planning and Management for Marine and Coastal Sustainability in Viet Nam. Gland and Hanoi: IUCN.

Islam, Saidul. 2014. Confronting the Blue Revolution: Industrial Aquaculture and Sustainability in the Global South. Toronto: University of Toronto.

Kaika, Maria. 2006. Dams as Symbols of Modernization: The Urbanization of Nature between Geographical Imagination and Materiality. Annals of the Association of American Geographers 96: 276-301. [CrossRef]

Lebel, Louis, Nguyen Hoang Tri, Amnuay Saengnoree, Suparb Pasong, Urasa Buatama, and Le Kim Thoa. 2002. Industrial Transformation and Shrimp Aquaculture in Thailand and Vietnam: Pathways to Ecological, Social, and Economic Sustainability? AMBIO: A Journal of the Human Environment 31: 311-23. [CrossRef]

Lebel, Louis, Po Garden, and Masao Imamura. 2005. The Politics of Scale, Position, and Place in the Governance of Water Resources in the Mekong Region. Ecology and Society 10: 610-11. [CrossRef]

Loftus, Alex. 2006. Reification and the Dictatorship of the Water Meter. Antipode 38: 1023-45. [CrossRef]

Loftus, Alex. 2009. Rethinking Political Ecologies of Water. Third World Quarterly 30: 953-68. [CrossRef]

Lukas, Martin C. 2014. Eroding Battlefields: Land Degradation in Java Reconsidered. Geoforum 56: 87-100. [CrossRef]

Martinez-Alier, Joan. 2002. The Environmentalism of the Poor. Cheltenham: Edward Elgar Publishing.

Milligan, Jessica, and Tim O'riordan. 2007. Governance for Sustainable Coastal Futures. Coastal Management 35: 499-509. [CrossRef]

Molle, François, Louis Lebel, and Tira Foran. 2009. Contested Mekong Waterscapes: Where to Next? In Contested Waterscapes in the Mekong Region. Hydropower, Livelihoods and Governance. Edited by F. Molle, T. Foran and M. Kakonen. London and New York: Routledge Earthscan, pp. 383-414. [CrossRef] 
Moore, Jason W. 2011. Transcending the Metabolic Rift: A Theory of Crises in the Capitalist World-Ecology. Journal of Peasant Studies 44: 594-630. [CrossRef]

Muradian, Roldan, Mariana Walter, and Joan Martinez-Alier. 2012. Hegemonic Transitions and Global Shifts in Social Metabolism: Implications for Resource-Rich Countries. Introduction to the Special Section. Globa Environmental Change 22: 559-67. [CrossRef]

Nguyen, Quy-Hanh, and Hans-Dieter Evers. 2011. Farmers as Knowledge Brokers: Analysing Three Cases from Vietnam's Mekong Delta. ZEF Working Paper Series 86: 1-46.

Nichols, Karen. 1999. Coming to Terms with 'integrated Coastal Management': Problems of Meaning and Method in a New Arena of Resource Regulation. Professional Geographer 51: 388-99. [CrossRef]

O’Hagan, A. M., and R. C. Ballinger. 2010. Implementing Integrated Coastal Zone Management in a National Policy Vacuum: Local Case Studies from Ireland. Ocean and Coastal Management 53: 750-59. [CrossRef]

Perreault, Tom, Gavin Bridge, and James McCarthy. 2015. The Routledge Handbook of Political Ecology. London and New York: Routledge. [CrossRef]

Pincetl, Stephanie, Paul Bunje, and Tisha Holmes. 2012. An Expanded Urban Metabolism Method: Toward a Systems Approach for Assessing Urban Energy Processes and Causes. Landscape and Urban Planning 107: 193-202. [CrossRef]

Ramesh, Devaraj Asir, and Arumugam Senthil Vel. 2011. Methodology of Integrated Coastal Zone Management Plan Preparation-Case Study of Andaman Islands, India. Journal of Environmental Protection 2: 750-60. [CrossRef]

Reis, Nadine. 2016. Good Governance as Managerialism: Rationalisation and International Donors in Vietnam's Rural Water Supply and Sanitation Sector. Development Policy Review 34: 29-54. [CrossRef]

Robbins, Paul. 2004. Political Ecology, A Critical Introduction. Chichester: Wiley Blackwell.

Schulz, Karsten, and Rapti Siriwardane. 2015. Depoliticised and Technocratic? Normativity and the Politics of Transformative Adaptation. Earth System Governance Working Paper 33: 1-29.

Sekhar, Nagothu Udaya. 2005. Integrated Coastal Zone Management in Vietnam: Present Potentials and Future Challenges. Ocean and Coastal Management 48: 813-27. [CrossRef]

Smith, Neil. 1984. Uneven Development: Nature, Capital and the Production of Space. New York: Basil Blackwell.

Swyngedouw, Erik. 2004. Social Power and the Urbanization of Water. Oxford: Oxford University Press.

Swyngedouw, Erik. 2011. Depoliticized Environments: The End of Nature, Climate Change and the Post-Political Condition. Royal Institute of Philosophy Supplement 69: 253-64. [CrossRef]

Swyngedouw, Erik. 2014. 'Not a Drop of Water...': State, Modernity and the Production of Nature in Spain, 1898-2010. Environment and History 20: 67-92. [CrossRef]

Swyngedouw, Erik, and Nickolas C. Heynen. 2003. Urban Political Ecology, Justice and the Politics of Scale. Antipode 35: 898-918. [CrossRef]

Thi Thanh Vinh, Do. 2006. Aquaculture in Vietnam: Development Perspectives. Development in Practice 16: 498-503. [CrossRef]

Tiller, Rachel, Tove Brekken, and Jenniver Bailey. 2013. Norwegian aquaculture expansion and Integrated Coastal Zone Management (ICZM): Simmering conflicts and competing claims. Marine Policy 36: 1086-95. [CrossRef]

UNEP. 2016. Annual Report 2016: Empowering People to Protect the Planet. UNEP Reports 1-8. Available online: https:/ / wedocs.unep.org/bitstream/handle/20.500.11822/19529/UN\%20Environment\%202016\% 20Annual\%20Report.pdf? sequence=1\&isAllowed=y (accessed on 23 January 2018).

Waibel, Gabi. 2010. State Management in transition: Understanding Water Resources Management in Vietnam. Working Paper-Center For Development Research 55: 1-59.

Zinzani, Andrea. 2015. The Logics of Water Policies: The IWRM Implementation in Uzbekistan and Kazakhstan. Zurich: LIT Verlag.

Zinzani, Andrea. 2018. Development initiatives and transboundary water politics in the Talas waterscape (Kyrgyzstan-Kazakhstan): Towards the Conflicting Borderlands Hydrosocial Cycle. In Water, Technology and the Nation-State. Edited by Filippo Menga and Erik Swyngedouw. London and New York: Routledge Earthscan.

(C) 2018 by the author. Licensee MDPI, Basel, Switzerland. This article is an open access article distributed under the terms and conditions of the Creative Commons Attribution (CC BY) license (http:/ / creativecommons.org/licenses/by/4.0/). 